\title{
REACTIONS, REPLIES, REFLECTIONS
}

Mr. D. G. Arnott, Senior Research Fellow in Development Studies at the University of Bradford wrote to us with comments on the section on Development Myths in Bulletin No. 4. With his permission we are printing the following extracts from his letter:

"I have just read through the bulletin with great interest and not a little exhilaration. I shall circulate it to a number of people here. But I am going to take the liberty of commenting on page 31. It is on the whole extremely salutory to write about development myths as has been done in this issue; but I do think that you should beware of introducing your own. And certainly the description of experts which appears in the second paragraph of page 31 has quite a lot of mythology about it. I have met experts like this but I would not say that they form the majority. I have met many who were deeply worried about the nature of their assignments and frequently tried to re-orientate them. In this they were of ten frustrated by local officials, more often still by remote Headquarters staffs.

Certainly experts do dress and eat differently from local inhabitants. They could of course live in mud huts, go without shoes, subsist upon cassava and drink unfiltered water. I believe it has been tried in some eccentric cases. I need not bother to point out the probable consequences to health and the refore to the assignment. I do not know where the experts are who "live in luxury unattainable at home"; I should be fascinated to have some details. In my experience those who are in UN service are as likely as not to be in debt. I would certainly admit that many of them keep their own company more than they should although I have known plenty that do not; unfortunately it frequently happens that nobody is particularly interested in assisting them to break out of this, even when they obviously wish to do so. The sort of familiarisation with local conditions that is necessary is usually lacking, and again in this respect the UN is a bad offender. You are right in saying that many unsuited people get recruited but your explanation is wrong. It is usually the result of ineptitude and ignorance on the part of recruiting staffs at Headquarters, at which it is 
comparatively rare to meet anybody who has both field experience and a position of authority.

Experts in fact are as often as not the victims of circumstances which they do not know how to use to the advantage of their assigmments. Added to which the majority of them are mateurs in the sense that they have little or no experience of what is involved in being an expert. Technical assistance has in fact an ingrained amateur status and recruitment is quite haphazard. From the expert's point of view it represents little more than an interesting but irrelevant interruption to his career and he is seldom encouraged by those responsible to take a more enlightened view of things Nor is there much chance that he will be enabled to spend sufficient of his life in field services to become a really competent performer. Even should he prove outstandingly successful at his first mission (which does sometimes happen though circumstances are against it) it is unlikely that any effort will be made by his Headquarters to retain his services because they are on the whole unlikely to appreciate his value. The reason for this is that they (like I suspect your correspondent) are neither technical people nor field workers and simply do not know the score." 